\title{
El midrash y la hagadá, fuentes de la iconogra- fía bíblica del prólogo miniado de la Hagadá de Sarajevo*
}

\author{
Galia Pik Wajs \\ Universidad Autónoma de Madrid
}

RESUMEN. El Museo Nacional de Bosnia conserva un códice litúrgico sefardí, datado a mediados del siglo XIV, y conocido comúnmente como Hagadá de Sarajevo. Fiel a la tipología y estructura tradicionales de las hagadot hispanas bajomedievales, la obra comienza con un ciclo miniado de temática bíblica. Los treinta y cuatro folios iluminados a toda página describen escenas basadas en los cinco libros del Pentateuco, la Torá, comenzando con la Creación y finalizando con la bendición de Moisés antes de su muerte. A pesar de ser su principal fuente de inspiración la Biblia, muchos de los episodios revelan una segunda dependencia textual: el vasto repertorio legendario judío, el midrash. Una selección de escenas permite comprobar esta filiación.

Palabras clave: Hagadá de Sarajevo, miniatura hebrea, hagadá, midrash, iconografía.

ABSTRACT. The Bosnian National Museum houses a mid-fourteenth-century liturgical sephardi manuscript commonly known as the The Sarajevo Haggadah. Remaining loyal to the traditional medieval spanish haggadot structure, the codex opens out with a sequence of biblical episodes. The thirty-four full-page miniatures depict episodes from the five books of the Pentateuch, the Tora, beginning with the Creation of the World and ending with Moses' blessing before his death. Despite of the fact that the principal inspiration source of the scenes is the Bible, many of the illustrations reveal another textual dependence: the large legendary Jewish material, the Midrash. A selection of scenes verifies this relationship

Key words: Sarajevo Haggadah, Jewish miniature, haggadah, midrash, iconography.

\section{LA HAGADÁ DE SARAJEVO. BREVE ESTADO DE LA CUESTIÓN.}

En el año 1898 los historiadores David Heinrich Müller y Julius von Schlosser rompieron una lanza por una de las mani-

* El presente trabajo se inscribe en el marco de una futura Tesis Doctoral versada sobre la Hagadá de Sarajevo y elaborada bajo la dirección de la Dra. María del Carmen Muñoz Párraga.

Quiero agradecer al profesor Fernando Galván Freile el apoyo y consejo que me brindó en mis prime- festaciones artísticas que, hasta el momento, había sido completamente olvidada por los especialistas: la aportación del pueblo judío al campo de las artes. Su obra, Die

ros pasos dentro del complejo mundo de la miniatura hebrea. Asimismo, aprovecho la presente publicación para agradecer, de una forma muy especial y con un profundo afecto, todo las oportunidades, consejos, y sobre todo, apoyo y aliento, al profesor de la Universidad de Zaragoza Dr. Jesús Criado Mainar, sin cuyos primeros ánimos no me hubiese atrevido a aventurar en el complejo mundo de la investigación artística. 
Haggada von Sarajevo ${ }^{1}$, supuso un primer acercamiento a lo que entonces se vino a llamar "miniatura judía" ${ }^{2}, \mathrm{y}$, más concretamente, a la iluminación de una tipología concreta de libro litúrgico judío: la Hagadá shel Pésaj ${ }^{4}$. La publicación de Müller y

${ }^{1}$ D. H. MÜlLER; J. SCHLOSSER, Die Haggadah von Sarajevo. Eine spanische-judische handschrift des Mittelalters. Nebst einem Anhange von David Kaufmann, Viena, 1898

${ }^{2}$ La validez del concepto de miniatura judía ha sido debatido prácticamente desde el momento en que dichas manifestaciones artísticas del pueblo hebreo comenzaron a ser estudiadas. Aunque siguen existiendo diferentes puntos de vista, en la actualidad la gran mayoría de estudiosos parece ponerse de acuerdo en negar la existencia de un estilo artístico netamente judío y prefiere hablar de miniatura hebrea, poniendo de relieve su dependencia de las escuelas de iluminación contemporáneas en cada uno de los lugares donde fue creada (esto es, miniatura hebrea peninsular, miniatura hebrea germana, etc.). En realidad esta controversia se extiende más allá del campo de la decoración miniada, y han sido varios los autores que se han peguntado acerca de la existencia de un arte judío. Para el debate referente al arte judio ver E. HOROWITZ, «Existe-t-il un art juif? Le peuple de l'image: les juifs et l'art», Annales HSS, año 56, no 3, París, 2001, pp. 665684 ; F. LANDSBERGER, «The Problem of Jewish Art», A History of Jewish Art, Nueva York-Londres, 1946, pp. 314; H. ROSENBERG, «Is there a jewish art?», Commentary, no 42:1, Nueva Cork, 1966, pp. 57-60. En relación a la noción de miniatura judía, ver F. GALVÁN FREILE, «Manuscritos iluminados en Sefarad durante los siglos del medievo», Memoria de Sefarad <catálogo de exposición>, Madrid, 2002, pp. 309-319; B. NARKISS, «Manuscritos iluminados hispanohebreos», La vida judía en Sefarad <catálogo de exposición>, Madrid, 1991, pp. $169-196$

${ }^{3}$ Con el fin de facilitar la lectura de los términos hebreos se ha simplificado al máximo la transcripción de los mismos respetando las reglas de la fonética española.

${ }^{4}$ Hagadá (pl. hagadot): sustantivo femenino del verbo hebreo lehagid, 'relatar'. En el judaísmo, y a lo largo de los tiempos, el término ha sido aplicado a diferentes materiales narrativos pertenecientes al cuerpo de la erudición rabínica no jurídica; lo único que tenían en común unos con otros era el hecho de incluir leyendas, anécdotas y parábolas que sirven para ilustrar los principios religiosos y éticos de la ley tradicional. La Hagadá por antonomasia es la llamada Hagadá shel Pésaj, el texto de lectura prescriptiva en la celebración judía de la festividad de Pésaj, la Pascua. La temática del presente estudio obliga a una referen-
Schlosser se ocupó de forma casi monográfica de un manuscrito, la Hagadá conservada en el Museo Nacional de Bosnia conocida comúnmente como Hagadá de Sarajevo, aunque incluía referencias y estudios iconográficos de otras catorce hagadot, ocho sefardís y seis ashkenazís ${ }^{5}$. La obra, en dos volúmenes, no pasó de ser un catálogo descriptivo de las diferentes miniaturas que componen cada una de las hagadot, con ciertas puntualizaciones sobre el estilo e iconografía que distinguen a los ejemplares hispanos de aquellos realizados en territorio germano.

Aunque en el año 1953 se reprodujeron por primera vez en color algunas de las escenas miniadas de la Hagadá ${ }^{6}$, no fue hasta diez años después cuando vieron la luz el conjunto de las mismas, en una edición facsímil editada a cargo del historiador judío Cecil Roth ${ }^{7}$. El texto introductorio aportaba interesantes datos sobre la historia del manuscrito, su posible origen catalán, y sus avatares por tierras europeas tras la expulsión de 1492, así como una descripción formal, muy similar a la ofrecida sesenta años antes por Müller y Schlosser. Una segunda edición facsimilar fue publicada en la década de los ochenta, cuyo estudio introductorio corrió a cargo de Eugen Werber ${ }^{8}$. Este nuevo estudio retomaba gran

cia minuciosa tanto a la Hagadá entendida como material legendario, como a la Hagadá shel Pésaj. Ambas se abordarán a lo largo de este trabajo.

${ }^{5}$ Atendiendo a criterios culturales y geográficos, el judaísmo medieval aparece dividido en dos grandes ramas: la sefardí y la ashkenazí. Mientras la primera hace referencia a las comunidades judías ubicadas en la Península Ibérica y norte de África, la segunda está relacionada con aquellas comunidades asentadas en el norte, centro y este de Europa.

${ }^{6}$ S. RADOJČIĆ, Haggadah of Sarajevo, Belgrado, 1953. La obra contiene siete reproducciones en color, acompañadas de un breve prólogo del autor, profesor de la Universidad de Belgrado.

${ }^{7}$ C. RотH, The Sarajevo Haggadah and its significance in the History of Art, Belgrado, 1975.

${ }^{8}$ E. WERBER, The Sarajevo Haggadah, Sarajevo, 1988. 
parte de los datos que habían ofrecido años atrás Müller y Schlosser y Cecil Roth, aunque se completaba con un interesante apartado aclaratorio relativo a la celebración de la Pascua judía, sus costumbres, tradiciones, significado y origen, así como una minuciosa descripción de los diferentes apartados que componen la Hagadá.

La decoración miniada de la Hagadá de Sarajevo ha sido abordada, al margen de las obras monográficas ya citadas, por un amplio conjunto de especialistas que, a través de diferentes estudios de conjunto sobre la miniatura hebrea peninsular, han hecho referencias más o menos extensas a la misma. Sin embargo, más de cien años después de la publicación pionera de Müller y Schlosser la bibliografía artística carece de un estudio sistemático de la obra, con una aproximación que vaya más allá de un mero análisis formal, y ofrezca un examen profundo y riguroso de la misma.

\section{LA HAGADÁ Y EL MIDRASH.}

Antes de abordar la problemática concreta de esta publicación, esto es, la literatura midráshica como fuente de la iluminación de la Hagadá de Sarajevo, nos parece preciso dedicar unas breves líneas a aclarar qué son la Hagadá shel Pésaj y el midrash.

\section{a) Hagadá shel Pésaj}

Nos limitaremos a aportar aquellos aspectos del Libro que nos parecen relevantes para poder abordar un estudio de su iluminación?. La Hagadá shel Pésaj es aquel

-

${ }^{9}$ Son innumerables los estudios relacionados tanto con la festividad de la Pascua judía, como con la Hagadá shel Pésaj, y su enumeración aquí sería imposible, por lo que nos limitamos a ofrecer las obras más relevantes en lengua castellana: A. C. AvRIL; D. MAISONNEUVE, Las fiestas judias, Estella, 1996; J. BARYLKO, Breve Historia de Pésaj, Buenos Aires, 1968; P. KLENICKI, La Celebración de la Pascua, Buenos Aires, 1984; I. MiHALOVICI, Fiestas y prácticas judías en el Talmud y en la Tradición, Barcelona, 2000, pp. 31-41; E. C. SCHLESINGER, libro que contiene el ritual y las lecturas propias de la celebración de la noche de Pésaj. Su finalidad principal es la de cumplir el mandato divino recogido en el segundo libro de la Torá ${ }^{10}$ : "Ese día explicarás a tus hijos: hacemos esto para recordar lo que hizo por mí el Señor cuando salí de Egipto" (Ex 13:8). Así, la Hagadá cumple el deber sagrado de todo judío de contar a sus hijos las maravillas hechas por Dios para redimir a los hebreos de la esclavitud de Egipto. Al margen de esta narración del Éxodo judío, el texto de la Hagadá shel Pésaj contiene diferentes pasajes de la Torá, del Talmud $^{11}$, midrashim ${ }^{12}$, así como himnos y anécdotas, cuya finalidad es la de trasmitir a los más pequeños de la casa el gran milagro obrado por Dios. En este punto debe señalarse que, al contrario que todos los demás libros rituales judíos, concebidos para ser leídos en la sinagoga, la Hagadá shel Pésaj está pensada para un uso doméstico, en una ceremonia en la cual, tal y como ya se ha dicho, los niños tienen un protagonismo especial. Este carácter doméstico de la Hagadá shel Pésaj es clave para comprender la singularidad de sus ilustraciones.

Originalmente, y hasta la Edad Media, los textos propios de la Hagadá shel Pésaj estaban incluidos en el corpus general de oraciones, esto es, como parte de los

Tradiciones y costumbres judías. Un viaje alrededor del año hebreo, Buenos Aires, 1970; Y. VAINSTEIN, El ciclo del año judío, Jerusalem, 1986, pp. 164-178.

${ }^{10}$ Torá: en sentido estricto, el nombre con el cual el judaísmo designa el Pentateuco (Génesis, Éxodo, Levitico, Números y Deuteronomio). En un sentido más general, el término hace referencia a la doctrina del judaísmo que, según la tradición, fue revelada a Moisés en el Monte Sinái, esto es, tanto la Ley Escrita, recogida en la Biblia, como la Ley Oral, transmitida de maestro a discípulo, y recogida en diversas recensiones.

${ }^{11}$ Talmud: ver anexo de fuentes comentadas.

${ }^{12}$ Midrash (pl. Midrashim): en sentido general, el término midrash hace referencia a la interpretación de la escritura. No nos detenemos en ofrecer una explicación más concisa, ya que se le dedicará un apartado en el presente texto. 
diferentes sidurim $^{13}$ y mahzorim ${ }^{14}$. Sin embargo, su carácter eminentemente doméstico y pedagógico incitó, allá por el siglo XII, su separación del libro oracional, para convertirse en un libro ritual independiente ${ }^{15}$. Estas características del texto hagádico son, precisamente, aquellas que mejor pueden explicar los motivos por los que, en el siglo XIII, se generalizó entre los judíos más acaudalados la costumbre de iluminar ricamente las hagadot: la inclusión de ilustraciones tenía como finalidad primera despertar el interés de los más pequeños, y mantener su atención a lo largo de la agotadora ceremonia, básicamente oral, del Séder shel Pésaj ${ }^{16}$. Volveremos sobre las características propias de las hagadot hispanas iluminadas más adelante.

\section{b) Midrash (Midrash hagadá)}

Abordar cualquier concepto relativo a la literatura religiosa hebrea no es tarea fácil e intentar exponer en unas breves líneas la complejidad del pensamiento judío y de sus reglas exegéticas, se nos antoja misión quimérica. En ningún caso es nuestra intención adentrar al lector en los entresijos del corpus hermenéutico judaico, sino tan sólo ofrecer unas líneas explicativas

${ }^{13}$ Sídur (pl. sidurim): Libro de Oraciones que contiene la liturgia diaria.

${ }^{14}$ Majzor (pl. majzorim): Libro de Oraciones que contiene la liturgia de las festividades mayores.

${ }^{15}$ Para un estudio sobre la formación del texto actual de la Hagadá shel Pésaj, así como las primeras versiones como texto independiente, ver P. GOODMAN, The Passover Anthology, Philadelphia, 1966, pp. 72-77.

${ }^{16}$ Séder shel Pésaj o, simplemente, Séder (en hebreo, "orden"): ceremonia doméstica que tiene lugar la primera noche (o las dos primeras noches, en el caso de la Diáspora) de la celebración de la Pascua judía. Tiene una estructura fija, siendo sus principales características la recitación del Kidush (oración de consagración y santificación del día), la lectura de la Hagadá shel Pésaj, la ingestión de ciertos alimentos simbólicos, sobre alguno de los cuales volveremos más adelante, la bebida de cuatro copas de vino y la recitación del Halel (canto de alabanza basado en el texto de Sal 113118). básicas que faciliten la comprensión del presente estudio artístico ${ }^{17}$.

En líneas generales el concepto de Literatura midráshica hace referencia al corpus de textos rabínicos relativos a la interpretación de los Libros Sagrados. Así, tal y como indica su raíz hebrea, derash, (en hebreo, “interpretación"), los midrashim comentan, explican y, sobre todo, interpretan, la Escritura bíblica; tomando prestadas las palabras de la Doctora Elena Romero el derash, "es un sistema interpretativo que intenta averiguar lo oculto, lo que se esconde tras el sentido superficial de las palabras y que trascendiéndolas, busca llegar al pleno conocimiento de la palabra de Dios" ${ }^{18}$. Dependiendo del material literario que comenten, los midrashim pueden ser de dos clases: midrash halajá, si su comentario hace referencia a textos bíblicos de índole legal, y midrash hagadá si afectan a material narrativo de las Sagradas Escrituras. En el caso del estudio que nos ocupa, el material midráshico al que haremos referencia será, en todo caso, hagádico.

El sistema hermenéutico judío es muy variado, y muchos los caminos por los que los exegetas hebreos se han acercado al texto bíblico con el propósito de conocer en

\footnotetext{
${ }^{17}$ Son muchas las obras que se han dedicado a descifrar los entresijos de la hermenéutica hebrea, y su complejidad varía según el público al que estén destinadas. Se trata, en la gran mayoría de los casos, de textos de autoría extrajera que rara vez han sido traducidos a lengua castellana. En los últimos años, el gran auge de los estudios hebraicos ha fomentado la aparición de algunos estudios en nuestro idioma que intentan ofrecer unas nociones básicas sobre el tema ver A. SÁENZ-BADIllos, J. TARGARONA BORRÁs, Los judíos de Sefarad ante la Biblia. La interpretación de la Biblia en el Medievo, Córdoba, 1996, así como la selección bibliográfica que lleva anexa. De igual interés, aunque tal vez de más fácil lectura, el magistral texto introductorio de la obra de E. ROMERO, La Ley en la Leyenda. Relatos de tema bíblico en las fuentes hebreas, Madrid, 1989, pp. 2-44.

${ }^{18}$ Ibid., p.19.
} 
profundidad el mensaje divino ${ }^{19}$. Mientras una parte de estas vías se basan en el desmenuzamiento lingüístico ${ }^{20}$, otras se detienen en el contenido narrativo propiamente dicho. Nos limitaremos a exponer aquellas empleadas para conformar el material hagádico al que haremos referencia más adelante.

Los midrashim se fundamentan en la concepción del texto bíblico como incompleto. Así, el derash se permite, cuando lo cree necesario, completar y ampliar dicho texto, con el fin de rellenar aquellos espacios que considera vacíos, o completar aquellos pasajes que entiende como demasiado escuetos. Al igual que ocurre en la exégesis cristiana, muchos de los pasajes son explicados no sólo en su propio contexto, sino a la luz de otros fragmentos bíblicos, relacionándolos a través de palabras que se repiten en ambos. Esta identificación de textos se lleva incluso más allá, identificando personas, animales, objetos, e incluso lugares, sin tener en cuenta ningún tipo de rigor cronológico o geográfico. En esta misma línea de perfeccionar el texto bíblico, muchos pasajes hagádicos desarrollan o amplían conversaciones entre los protagonistas de la narración. Estos procedimientos exegéticos, junto a muchos otros en los que, tal y como ya se ha señalado antes, no nos detendremos, conforman "un material literario nuevo en el cual el relato bíblico subyacente resulta

-

${ }^{19}$ Para un estudio en profundidad de la metodología midráshica, ver A. DíEZ MACHO, El Targum: Introducción a las traducciones aramaicas de la Biblia, Madrid, 1982. Para un texto más asequible, en el que se incluyen interesantes ejemplos que facilitan la comprensión, ver E. ROMERO, La Ley en la Leyenda. Relatos de tema bíblico en las fuentes hebreas, op. cit., pp. 20-27.

${ }^{20}$ Así, las reglas hermenéuticas se proyectan sobre cada letra, segmento de palabra, palabra, sintagma, frase y versículo del texto. Estas reglas se basan generalmente en los valores numéricos otorgados a las letras, en la identificación de diferentes raíces para una misma palabra, la presencia o ausencia de ciertos artículos, empleo de fórmulas repetitivas, expresiones paralelas, etc. elucidado, ampliado o concretado a tenor de la creatividad del comentarista" ${ }^{21}$.

Llegado este punto, y antes de pasar a abordar la problemática central de este estudio, debe hacerse una última puntualización en relación con aquello que hemos venido llamando literatura exegética y aclarar que el material midráshico se transmitía, en sus orígenes, de forma oral; según detalla la tradición judía, junto a la Torá Escrita que fue entregada a Moisés en lo alto del Sinaí, éste recibió una explicación oral detallada de todo aquello que se le estaba dictando; este material oral fue transmitido de generación en generación, pero llegó un momento en el que ya no bastó con la memoria para conservarlo. Fue alrededor del año 100 a.C. cuando surge, por primera vez, la necesidad de fijar por escrito toda esta vasta herencia que, a su vez, fue ampliada con las disertaciones de los rabinos y otras personalidades de la vida religiosa judía. Esta labor se dilató a lo largo de varios siglos, y en el siglo XIX todavía observamos sus últimos coletazos. Sería imposible, y poco práctico, incluir en el presente texto una aproximación al desarrollo histórico y literario del Midrash, por lo que, a modo de anexo, comentaremos de forma breve aquellas compilaciones midráshicas citadas en el análisis iconográfico ${ }^{22}$.

\section{LA HAGADÁ DE SARAJEVO: UNA HAGADÁ ILUMINADA HISPANO- MEDIEVAL.}

Aunque no son muchos los ejemplares de hagadot sefardís iluminadas que han

\footnotetext{
${ }^{21}$ E. ROMERO, La Ley en la Leyenda. Relatos de tema bíblico en las fuentes hebreas, op. cit., p. 24.

${ }^{22}$ Ver anexo. Para una lectura detallada sobre la formación del corpus midráshico y una relación de las obras más relevantes ver E. ROMERO, La Ley en la Leyenda. Relatos de tema bíblico en las fuentes hebreas, op. cit., pp. 15-44.
} 
llegado hasta nuestros días ${ }^{23}$, los conservados guardan, en su gran mayoría, un esquema muy similar al de la Hagadá de Sarajevo. Tanto esta estructuración en secciones concretas, como la disposición de la decoración, las distinguen de los prototipos de origen ashkenazi $i^{24}$ : mientras las germánicas se caracterizan por las ilustraciones marginales, colocadas junto al texto, en las hagadot sefardís dichas ilustraciones marginales son escasas, conteniendo la gran mayoría de ellas miniaturas a toda página que, a modo de prólogo miniado, y normalmente en cuadernos independientes, preceden al

\footnotetext{
${ }^{23}$ Actualmente se tiene noticias de quince ejemplares conservados, incluyendo el que nos ocupa: Hagadá de Sarajevo (Sarajevo, Narodna i univerzitetska Bosne i Hercegovine); Hagadá de Barcelona (Londres, The British Library, Ms. Add. 14761); Hagadá de Oro (Londres, The British Library, Ms. Add. 27210); Hagadá catalana, conocida como Sister Haggada (Londres, The British Library, Ms. Add. 2884); Hagadá sefardí, conocida como Brother Rylands Haggada (Londres, The British Library, Ms. Or. 1404); Hagadá Hispano Morisca (Londres, The British Library, Ms. Or. 2737); Hagadá Rylands (Manchester, The John Rylands University Library, Ms. Ryl. Hebr. 6); Hagadá Kaufmann (Budapest, Magyar Tudományos Akadémia, Ms. A 422); The Sassoon Haggadah (Jerusalén, The Israel Museum - hasta su adquisición en fechas recientes por el Israel Museum de Jerusalén, el manuscrito pertenecía a la colección de Library of Rabbi Sassoon, Ms. 514-); Graziano Haggadah (Nueva York, Library of the Jewish Theological Seminary of America, Ms. 9300 - esta catalogación moderna se corresponde con el manuscrito Ms. Adler 1337-); Prato Haggadah (Nueva York, Library of the Jewish Theological Seminary of America, Ms. 9478); Hamilton Haggadah (Tübingen, Tübinger Depot der Preussiscehn Staatbibliothek, Ms. Or. Hamilton 288 - esta catalogación moderna se corresponde con el manuscrito Ms. Or. Hamilton 28812); Hagadá de Parma (Parma, Biblioteca Palatina, Ms. Parm. 2411); Hagadá (Roma, Biblioteca Casanatense, Ms. 2761); Hagadá — consevada en dos fragmentos- (Bologna, Biblioteca Universitaria, Ms. 2559 y Módena, Biblioteca Esténse, cod. alfa. K.I.22); Hagadá de Poblet (Poblet, Abadía de Santa María, Ms. 100).

${ }^{24}$ Aunque en este estudio por motivos de delimitaciones temporales - las hagadot sefardís conservadas datan de los siglos XIII-XIV - únicamente hagamos referencia a las escuelas sefardí y ashkenazí, existió una tercera escuela decorativa, la italiana, cuyos restos conservados se retrasan hasta el siglo XV.
}

texto de la Hagadá. Este preámbulo pintado contiene escenas relativas al segundo libro de la Torá, el Éxodo, aunque, como en el caso que nos ocupa, en ciertas ocasiones dicho ciclo se amplía, abarcando hechos narrados en otros libros del Pentateuco. Estas decoraciones bíblicas suelen ir acompañadas por otras de carácter ritual, fundamentalmente de índole instructiva referentes a la preparación y celebración del Pésaj ${ }^{25}$.

A esta primera parte le sigue el texto hagádico propiamente dicho, escasamente decorado, seguido de una tercera, y última parte, que contiene una colección de piyu$\mathrm{tim}^{26}$, que raramente incluyen decoración.

La Hagadá que nos ocupa data de c.1350, fecha en que la tipología de Hagadá sefardí miniada está ya consolidada ${ }^{27}$, y sus tres partes perfectamente establecidas:

\section{-}

${ }^{25}$ Aunque nos limitemos a hacer referencia a las ilustraciones bíblicas y rituales, por ser aquellas que aparecen en las miniaturas a toda página que anteceden al texto, son cuatro las categorías en que, dependiendo del contenido, pueden dividirse las miniaturas de la Hagadá: las dos ya mencionadas, así como las decoraciones textuales y las de naturaleza escatológica. La práctica mayoría de autores que han tratado el tema de la Hagadá sefardí han hecho referencia a esta cuádruple división. La esencia de todo lo publicado, a modo de síntesis, puede leerse en Encylopaedia Judaica, vol. 7, Jerusalem, 1972, cols. 1096-1097.

${ }^{26}$ Piyutim: poemas litúrgicos que debían ser recitados en la sinagoga durante toda la semana de Pascua y el sábado anterior a la misma.

${ }^{27}$ Las iluminaciones de los textos pascuales datan de fechas anteriores al siglo XIV, aunque en ningún caso con la profusión y riqueza de imágenes que presentan las de la decimocuarta centuria. Los primeros fragmentos de Hagadá ilustrados datan del siglo X, cuando el texto todavía formaba parte del conjunto oracional judío, y fueron encontrados en la Genizah cairota. Para una mayor información sobre estos fragmentos, ver A. M. HABERMANN, The Cairo Genizah and other genizoth: Their character, contents and development (en hebreo), Jerusalem, 1971; P. E. KAHLE, The Cairo Geniza, Nueva York, 1960; D. KaufmanN, "Notes to the Egyptian Fragments of the Haggadah", Jewish Quarterly Review,10, Londres, 1898, pp. 380-381; 
1) Prólogo miniado. Ocupa los primeros 34 folios. Sus 69 miniaturas aparecen iluminadas sobre el lado de la carne, por lo que el lado del pelo queda sin iluminar. La distribución de los folios, haciendo coincidir los lados pelo y carne en páginas consecutivas, nos presenta las imágenes y los folios en blanco enfrentados dos a dos, esto es, a dos folios miniados les siguen otros dos en blanco. En los márgenes superior e inferior de cada una de las escenas pueden leerse los versículos bíblicos a los que dicha imagen hace referencia, o, en su caso, la descripción del acto ritual que tiene lugar en la misma.

El ciclo iluminado de la Hagadá de Sarajevo es el más extenso de los conservados, ya que comienza con la Creación del mundo (Génesis 1:1), y finaliza con la bendición de Moisés antes de su muerte (Deuteronomio 34:9). A estas escenas bíblicas siguen una representación del Templo de Jerusalén a página completa, y tres escenas rituales relativas a la celebración de la Pascua.

2) El texto hebreo de la Hagadá. Ocupa los cincuenta siguientes folios. Están escritos en ambos lados en una escritura sefardí cuadrada, y muchas de las palabras iniciales aparecen destacadas y ricamente decoradas. En el texto se intercalan tres miniaturas a toda página, así como otras, de menor tamaño, de tipo ritual y textual ${ }^{28}$.

3) Piyutim. Las últimas setenta y tres hojas contienen las poesías, plegarias y textos bíblicos pertinentes de ser leídos en los oficios ya mencionados.

S. REIF, A Jewish Archive from Old Cairo: the history of Cambridge University's Genizah collection, Londres, 2000.

${ }^{28}$ Para una descripción detallada de las miniaturas, tanto las que forman la introducción miniada, como aquellas que decoran el cuerpo textual, ver C. RоTH, The Sarajevo Haggadah and its significance in the History of Art, op. cit., pp. 17-25; E. WERBER, The Sarajevo Haggadah, op. cit., pp. 22-39.

\section{IV.FUENTES TEXTUALES DEL PRÓLO- GO MINIADO: EL MIDRASH ${ }^{29}$.}

A pesar de la existencia de algunas publicaciones monográficas sobre nuestro manuscrito $^{30}$, no cabe duda de que la gran mayoría de los aspectos relativos al mismo siguen pendientes de estudio. En las líneas siguientes intentaremos proporcionar algunas pistas sobre uno de estos aspectos: las fuentes textuales que inspiraron el prólogo miniado. La totalidad de los especialistas están de acuerdo en que la iconografía judía, al margen de inspirarse en los cinco Libros de la Torá, evidencia una segunda fuente de inspiración: los textos y tradiciones que integran su vasto material exegético. El caso de la Hagadá de Sarajevo no es una excepción, tal y como intentaremos demostrar con el análisis de algunas de sus escenas $^{31}$ :

Caín y Abel (Fol. 4r-registro superior-)

Pasado algún tiempo, Caín presentó al Señor una ofrenda de los frutos de la tierra. Abel le ofreció también los

${ }^{29}$ Nótese que en el mundo judío la lectura se realiza de derecha a izquierda. Este aspecto condiciona la lectura de las imágenes dentro de un mismo folio, ya que en la mayoría de los casos se presentan en el mismo sentido que la escritura.

${ }^{30}$ Ver notas 2, 6, 7 y 8.

${ }^{31}$ Haremos referencia a cada una de las escenas que vayamos a examinar citándolas según su temática y señalando su ubicación en el prólogo. A su vez, citaremos el versículo, o versículos, en que está basada la respectiva iluminación. En la práctica totalidad de los casos las palabras que acompañan a cada una de las imágenes están extraídas de dichos versículos bíblicos, aunque no recogen la totalidad del mismo. Por este motivo hemos optado por señalar en cursiva aquellas partes de la cita bíblica que efectivamente acompañan las ilustraciones. En algunos casos las frases aclaratorias a las imágenes no están tomadas del texto canónico, sino de otras fuentes hebreas, o son, sencillamente, añadidos y libres intervenciones del escriba-iluminador; transcribiremos dichas palabras encerradas entre corchetes []. En los casos en que las ilustraciones contengan más de un epígrafe aclaratorio, reflejaremos todos ellos, marcando la separación entre unos y otros mediante un cuadrado negro $\mathbf{m}$. 
primogénitos de su rebaño y hasta su grasa. El Señor se fijó en Abel y su ofrenda más que en Caín y la suya. Entonces Caín se enfureció mucho y andaba cabizbajo (Gen 4, 3-5) - Caín propuso a su hermano Abel que fueran al campo y, cuando estaban allí, se lanzó [Caín] contra su hermano Abel y lo mató (Gn 4,8)

La imagen reúne en una misma escena dos episodios diferentes de la narración (fig. 1): los sacrificios ofrecidos por ambos hermanos y el asesinato de Abel. Nos centraremos en esta segunda parte; en la escena Caín aparece abalanzado sobre su hermano atravesando su cuello con lo que parece un pequeño cuchillo. Es evidente que el iluminador de la Hagadá no pudo inspirarse en las escuetas palabras de la Biblia, ya que nada dicen las Sagradas Escrituras acerca del modo en que fue llevado a cabo el fratricidio, o el arma que en él fue empleada.

El Génesis Rabá se ocupa del episodio, analizando las palabras de la Torá. Así, Rabí Yojanán afirma que Abel era más fuerte que Caín, pues la Escritura dice "se levantó" precisamente para indicar que [Caín] estaba caído a sus pies ${ }^{32}$ cuando le dijo: "sólo nosotros dos estamos en el mundo, ¿qué vas a decirle a padre [si me matas]?" Y le perdonó, lleno de compasión por él, quién al momento se alzó contra él y le matón ${ }^{33}$. Pero el texto hermenéutico aún va más allá, al afirmar que las palabras bíblicas indican un objeto que produce heridas ${ }^{34}$. Por último, según Rabí Yisjak, Caín había visto a su padre, Adán, sacrificando a un novillo, e imitándolo mató a su hermano por el lugar del cuello y de sus órganos vitales ${ }^{35}$. Este último aspecto aparece también recogido en el Talmud de Babilonia, que afirma que Caín estuvo infligiendo golpes y heridas a Abel,

\footnotetext{
${ }^{32}$ En el transcurso de la pelea, Abel habría derivado a Caín.

${ }^{33}$ Bereshit Rabá, capítulo XXII, Gn 1-16.

${ }^{34}$ Ibid.

${ }^{35}$ Ibid.
}

sin saber por dónde salía el aliento, hasta que llegó al cuello ${ }^{36}$.

El decorador del prólogo miniado de la Hagadá de Sarajevo, conocía, sin duda, estas interpretaciones midráshicas. Aunque tuvo como fuente principal los versículos del Génesis, los detalles menores de la escena fueron tomados de los textos exegéticos, que amplían y aclaran la narración bíblica, aportando detalles vitales para la plasmación pictórica de la escena.

José y sus hermanos (Fol. 16r-registro superior-)

A José le sirvieron aparte. Y sirvieron por separado a ellos y a los egipcios que habían de comer allí, pues los egipcios no pueden comer con los hebreos, porque esto a los egipcios les es una abominación. Se sentaron en su presencia de esta manera: el primogénito de acuerdo con su rango hasta el más joven de acuerdo con su edad. Y los hombres se miraban atónitos unos a otros (Gn 43:32-33)

Pocos son los detalles que da el Génesis con relación al banquete ofrecido por José a sus hermanos; el texto se limita a indicar la separación entre los egipcios y los judíos (Gn 43:32), y añade que los hermanos fueron sentados a la mesa de acuerdo a su edad, detalle que llamó poderosamente su atención. ¿Por qué debían sentarse los judíos en una mesa aislada, separados de los egipcios? ¿Qué fue aquello que tanto llamó la atención de los hermanos de José? Las respuestas a todas estas preguntas se hallan en el Targum pseudo-Jonatán; en primer lugar nos aclara que la abominación de los egipcios, y el motivo por el que debían comer separados de los hebreos, tiene su origen en la comida: los primeros conside-

${ }^{36}$ Cain inflicted upon his brother many blows and wounds, because he knew not whence the soul departs [he did not know which blow would prove fatal], until he reached his neck [And severed the arteries], Orden Nezikim, Tratado Sanedrín 37b. 
raban sagrados algunos animales que los segundos no dudaban en ingerir ${ }^{37}$. En segundo lugar, y mucho más importante para entender la interpretación iconográfica, el Targum nos da la pista para comprender el modo en que José justificó ante sus hermanos el hecho de que estuvieran sentados en orden, de acuerdo a sus respectivas edades; José tomó una copa de plata y fingiendo tener dotes adivinatorias, la hacía sonar cada vez que sentaba a uno de sus hermanos a la mesa. Cuando estaban todos acomodados, se dieron cuenta de que los hijos de una misma madre estaban uno al lado del otro ${ }^{38}$, según sus edades ${ }^{39}$. En nuestra escena la copa adivinatoria, a mayor tamaño, preside la mesa, mientras José la señala, haciéndola sonar (fig. 2).

Muerte de José (Fol. 20r — registro superior一)

José murió a la edad de 110 años, y lo embalsamaron y lo pusieron en un ataúd en Egipto (Gn 50:26) [Los egipcios lo depositaron en el Nilo] [Egipto]

Es la Hagadá de Sarajevo el único manuscrito iluminado hebreo, de entre los conservados, que incluye en su ciclo la muerte de José (fig. 3). El texto bíblico es parco en palabras, y únicamente nos indica que el cuerpo del patriarca fue embalsamado e introducido en un ataúd (Gn 50:26). En la escena podemos ver un grupo de personajes encapuchados que sumergen el ataúd en un río. Si hacemos caso a las palabras añadidas de la parte superior, el río que vemos es el Nilo, y los personajes, egipcios. Sin embargo, si examinamos más detenidamente la escena, olvidándonos de las palabras superiores, los atavíos de los protagonistas, y su cabeza cubierta en señal de

-

${ }^{37}$ Targum pseudo-Jonatán Gn 43:32.

${ }^{38}$ Aunque todos hijos de Jacob, José y sus hermanos tenían distintas madres: Lea, Zilpá, Bilhá y Raquel, madre de José (Ver Gn 35:22-26).

${ }^{39}$ Targum pseudo-Jonatán Gn 43:33. luto $^{40}$, les delatan como judíos. Tal y como intentaremos demostrar, la escena recoge no una, sino dos tradiciones hagádicas distintas.

El comentario del Targum pseudoJonatán mantiene la creencia hebrea de que fueron los judíos quienes, tras introducir el cuerpo de José en el ataúd, lo sumergieron en el Nilo para evitar que los egipcios lo emplearan en sus ritos politeístas. Esta es la versión aportada por Werber en su análisis descriptivo del ciclo bíblico de la Hagadá ${ }^{41}$. Sin embargo, la inscripción de la parte superior, que afirma explícitamente que fueron los egipcios los que introdujeron el ataúd en el Nilo, obliga a buscar otra interpretación paralela. Ex 13:19 $9^{42}$ señala que en su salida de Egipto, Moisés llevó consigo los restos de José, cumpliendo la antigua promesa que los hijos de Israel le habían hecho a la hora de su muerte ${ }^{43}$. Una interpretación midráshica de este episodio cuenta que fueron los magos del faraón quienes introdujeron el cuerpo de José en un ataúd de metal y lo hundieron en el Nilo, con el fin de que los judíos jamás pudieran cumplir la promesa que hicieron a José de llevarse sus restos a la tierra de Israel, y así impedir la marcha del pueblo de Israel de Egipto $^{44}$. Mientras la escena recoge la pri-

${ }^{40}$ La costumbre de cubrirse la cabeza en señal de luto estuvo muy extendida en tierras hispanas a lo largo de todo el período medieval. Ver E. CANTERA MONTENEGRO: Aspectos de la vida cotidiana de los judíos en la España medieval, Madrid, 1998, p. 123.

${ }^{41}$ E. WERBER, The Sarajevo Haggadah, op. cit., pp. 30-31.

42 “Moisés llevó consigo los restos de José, porque éste había hecho jurar a los israelitas que se llevarían con ellos sus restos cuando Dios los liberase" (Ex 13:19).

43 "Entonces José hizo jurar a los hijos de Israel, diciendo: ciertamente Dios vendrá en vuestra ayuda; entonces vosotros haréis llevar de aquí mis restos" (Gen 50:25).

${ }^{44}$ Esta segunda versión hagádica del entierro de José está tomada de la compilación de E. ROMERO, La Ley 
mera tradición, el texto aclaratorio parece inclinarse por la segunda.

Esta discordancia entre texto e imagen, interpretando diferentes fuentes, tiene una sencilla explicación. Los encabezamientos de las imágenes delatan una intervención tardía, no contemporánea al resto del manuscrito ${ }^{45}$. Así, el escriba que añadió las palabras superiores no supo interpretar correctamente la intención del artista iluminador, añadiendo la paráfrasis targúmica, que era, en realidad, completamente ajena a la fuente de inspiración original de la imagen.

Rescate de Moisés (Fol. 20r —registro inferior-)

Entonces el faraón mandó decir a todo su pueblo: echad al Nilo a todo niño que nazca, pero a toda niña conservadle la vida (Ex 1:22) - Entonces la hija del faraón descendió al Nilo para bañarse. Y mientras sus doncellas se paseaban por la ribera del Nilo, ella vio la arquilla entre los juncos y envió a una sierva suya para que la tomase. Cuando la abrió, vio al niño; y he aquí que el niño lloraba. Y teniendo compasión de él, dijo: este es un niño de los hebreos (Ex 2:5-6) — Y la hija del faraón le dijo: llévate a este niño y críamelo. Yo te lo pagaré. La mujer tomó al niño y lo crió (Ex 2:9)

La hija del faraón, coronada y seguida por dos sirvientas, aparece de pie, en medio del río, a la izquierda de la imagen. Mientras una de sus manos parece tocar la cesta abierta, con la otra señala a las otras dos protagonistas de la escena, la madre y la hermana de Moisés, que permanecen de pie, en la otra orilla (fig. 3). ¿Por qué el iluminador nos presenta a la hija del faraón recogiendo la cesta de Moisés, cuando las

\footnotetext{
en la Leyenda. Relatos de tema bíblico en las fuentes hebreas, op. cit., p. 276.

45 C. ROTH, The Sarajevo Haggadah and its significance in the History of Art, op. cit., p. 21.
}

Sagradas Escrituras indican claramente que envío a una de sus criadas?

Estamos ante uno de los episodios veterotestamentarios que con mayor premura llamó la atención de los especialistas, debido a la discrepancia evidente entre la narración bíblica y la plasmación pictóri$\mathrm{ca}^{46}$. Al ser un ejemplo de interpretación midráshica sobradamente estudiado, nos limitaremos a exponer brevemente las conclusiones a las que han llegado los especialistas: los comentarios midráshicos y talmúdicos se detienen en examinar el término hebreo אמתה (amatah) que, dependiendo de la vocalización ${ }^{47}$, puede leerse de dos modos: mientras אמתה -amatah-significa su sirvienta, אפיתה -ammatah - debe leerse su brazo. Esta doble lectura tiene su origen en una discusión rabínica, recogida tanto por el Talmud como por los textos midráshicos ${ }^{48}$. A pesar de que la segunda lectura parece más verosímil a la luz del texto bíblico, de acuerdo al cual la hija del faraón descendió al Nilo para bañarse mientras sus doncellas se paseaban por la ribera del $\mathrm{Nilo}^{49}$, la traducción de la Vulgata prefirió la primera lectura, lo que explica que en la gran mayoría de ilustraciones cristianas la hija del faraón apa-

${ }^{46}$ En el año 1960 el Dr. Joseph Gutmann publicó un breve estudio acerca de la iconografía mosaica, en el que incluyó una interesante comparativa incluyendo varios ejemplos, tanto judíos como cristianos, del rescate de Moisés de las aguas. Ya en este temprano estudio señala las líneas básicas que permiten analizar de forma adecuada la escena. Ver J. GUTMANN, "The haggadic motif in Jewish iconography", Eretz-Israel, vol. VI, Jerusalem, 1960, pp. 16-22

${ }^{47}$ El sistema de escritura hebreo fue, en sus orígenes, consonántico. Es a partir del siglo $\mathrm{V}$ d. C cuando, muy lentamente, se comienza a fijar un complicado sistema de vocalización basado en 14 señales diacríticas que debían ser colocadas dentro, debajo o encima de la letra. Esto ocasionó, como en el caso que nos ocupa, un doble sentido de una misma palabra, dependiendo de la forma en que se hubiese vocalizado.

${ }^{48}$ Orden Nashim, Tratado Sotah, 12b y Shemot Rabá, cap. I, 23.

${ }^{49}$ Ex 2:5. 
rezca fuera del agua, mientras una de sus sirvientas baja a recoger el cesto. Sin embargo, aquellas miniaturas inspiradas en textos hebreos, como es el caso de nuestra escena, prefieren representar a la misma hija del faraón encontrando la cesta ${ }^{50}$.

La cuarta plaga (Fol. 23v - registro inferior-)

[ערוב] [arov]

Mientras Moisés y su hermano Aarón observan la escena, el faraón y otros personajes son atacados por una serie de animales imaginarios, tanto voladores como reptadores y cuadrúpedos (fig. 4). Nuevamente la representación varía de aquella que conocemos en las ilustraciones cristianas. El motivo radica, al igual que en el caso anterior, en la interpretación rabínica que se dio al término arov, voz con que la lengua hebrea denomina la cuarta plaga; su raíz ערב (arav) evoca la idea de mezcla, concepto que en las diferentes traducciones bíblicas derivó en multitud; mientras la Vulgata optó por traducirlo como una multitud de animales voladores (moscas o tábanos en las versiones castellanas), los rabinos judíos en los comentarios midráshicos dieron una interpretación diferente al término, afirmando que la cuarta plaga llegaría a tierras egipcias desde arriba y desde abajo ${ }^{51} \mathrm{y}$ consistiría en una mezcla de aves y animales ${ }^{52}$. Dos glosas distintas de un mismo término han generado, como en el caso del Rescate milagroso de Moisés, dos interpretaciones icnográficas diferentes: por un lado la inspirada en los textos de índole hebrea que, como en el caso que nos ocupa, se inclina por una multitud conformada por toda clase de animales (figs. 5 y 6); por otro lado, las

\footnotetext{
${ }^{50}$ Esta iconografía aparece en época muy temprana, como puede observase en las pinturas del muro occidental de la Sinagoga de Dura Europos, conservadas actualmente en el Museo Nacional de Damasco (Siria), y datadas en el siglo III d. C.

${ }^{51}$ Midrash Shemot, 8: 18 (vol. 3, p. 143)

${ }^{52}$ Ibid. (vol. 3, p. 144).
}

escenas inspiradas en los textos de traducción latina, que plasman la plaga a través de una multitud de insectos, moscas y mosquitos.

El paso del Mar Rojo (Fol. 28r — registro superior-)

Pero los hijos de Israel caminaron en seco por en medio del mar, teniendo las aguas como muro a su derecha y a su izquierda (Ex 14:29) a Moisés extendió su mano sobre el mar, y cuando amanecía, éste volvió a su lecho, de modo que los egipcios chocaron contra él cuando huían. Así precipitó Jehovah a los egipcios en medio del mar (Ex 14:27)

Los regimientos de caballería egipcios aparecen completamente anegados por las aguas del mar, mientras los hebreos avanzan a través de dos sendas paralelas (de la superior no vemos más que un pequeño fragmento), completamente secas (fig. 7). La escena, una de las más reproducidas del manuscrito, evidencia una doble inspiración hagádica. Según la tradición, y para evitar posibles peleas acerca de prioridades en la llegada tras cruzar el mar, fueron doce los senderos que se abrieron a través de las aguas, uno para cada una de las tribus. Este midrash aparece recogido en la narración hagádica de Rabí Eliezer ${ }^{53}$. Aunque alguna Hagadá contemporánea plasma la totalidad de los camino ${ }^{54}$ (fig. 8), otras, como la de Sarajevo, se limitan a sugerir la multiplicación de caminos con la plasmación de dos de ellos ${ }^{55}$ (fig. 9).

${ }^{53}$ Pirkei Rabí Eliezer, capítulo 52.

54 Hagadá (Roma, Biblioteca Casanatense, Ms. 2761) fol. 4.; en el caso de la llamada Sister Haggadah, los doce caminos son sugeridos a través de doce representantes que se disponen a cruzar el mar (Londres, The British Library, Ms. Add. 2884), fol. 16.v;

${ }^{55}$ La simplificación de los doce caminos en dos también puede verse en Hagadá Rylands (Manchester, The John Rylands University Library, Ms. Ryl. Hebr. 6), fol. 19; Hagadá - Brother Rylands Haggadah(Londres, The British Library, Ms. Or. 1404), fol. 7v. 
Pero la escena del Paso del Mar de la Hagadá de Sarajevo guarda una segunda sorpresa a los especialistas en iconografía: la figura coronada en el extremo de la imagen nos revela que, a pesar de las palabras bíblicas que atestiguan que no quedó ni un solo egipcio con vida ${ }^{56}$, uno de ellos sí sobrevivió: el faraón. Del siglo XI es el llamado Midrash Veyoshá que aclara como, en el último momento antes de perecer arrastrado por las aguas, el faraón se arrepintió y proclamó la Unicidad del Dios de los hebreos. Este arrepentimiento tardío le salvó de las aguas, pero le valió quince días de torturas en el fondo del mar, para ser finalmente coronado Rey de Niníve, pueblo cuya destrucción impidió consiguiendo el arrepentimiento de sus habitantes ${ }^{57}$. A su muerte, el faraón fue colocado en las puertas del Cielo, donde no duda en proclamar la grandeza de Dios cada vez que un monarca atraviesa la entrada ${ }^{58}$. No fue el artista de nuestra Hagadá el único que plasmó la narración midráshica del arrepentimiento del faraón, sino que existen muchos otros ejemplos, incluso cristianos, que se basaron en el texto hagádico. Todos estos ejemplos aparecen recogidos en sendos estudios monográficos de Bezalel Narkiss, director del Center of Jewish Art ${ }^{59}$, y del especialista en Arte bizantino, Carl Otto Nordström ${ }^{60}$, a los que remitimos para mayores detalles sobre los mismos.

56 Éxodo 14:28.

${ }^{57}$ La salvación de Nínive gracias a la intervención de su Rey aparece recogida en Jonás 3.

${ }^{58}$ El Midrash Veyoshá aparece recogido en L. GINZBERG, The Legends of the Jews, vol 3, BaltimoreLondres, 1998, pp. 29-30.

${ }^{59} \mathrm{~B}$. NARKISS, «Pharaoh is dead and Living at the Gates of Hell», Journal of Jewish Art, no 10 , Jerusalem, 1983, pp. 6-13.

${ }^{60}$ C. O. NORDSTRÖM, «The Water Miracles of Moses in Jewish Legend and Byzantine Art», Orientalia Suecana, 7, Uppsala, 1958, pp. 87-98. El texto fue recogido nuevamente en J. GUTMANN, ed., No Graven Images. Studies in Art and the Hebrew Bible, Nueva York, 1971, pp. 277-308
El Templo de Jerusalén (Fol. 32r)

[El Santo Templo que será pronto erigido, en nuestros días]

Estamos ante una de las tres miniaturas a toda página que incluye el prólogo miniado; siguiendo los prototipos del momento, el artista nos presenta, a través de una fábrica fortificada, el Templo de Jerusalén, en cuyo centro observamos el tabernáculo conteniendo las Tablas de la Ley (fig. 10). Esta imagen parece ciertamente fuera de lugar, ya que, a primera vista, no guarda relación alguna con los contenidos de los folios anterior y posterior; el folio $31 \mathrm{v}$ cierra, aparentemente, el ciclo bíblico, con las bendiciones de Moisés al pueblo de Israel (registro superior) y a su sucesor, Josué (registro inferior). El folio 33v, en cambio, contiene dos de las tres escenas de carácter ritual del prólogo miniado, las costumbres sefardís de repartir jaroset (registro superior) y matzá (registro inferior) ${ }^{61}$. ¿Cómo se explica la presencia del Templo de Jerusalén y del Tabernáculo al final del ciclo bíblico y antes de las narraciones de tipología ritual? La respuesta, una vez más, debe buscarse en el Midrash.

El Midrash Tanhuma-Yelamedenu señala la relación existente entre el Tabernáculo y la Creación del mundo, poniendo en relación la narración Génesis 1:1-2:3 con pasajes

\footnotetext{
${ }^{61}$ Tal y como indicábamos en la nota 16, una de las características de la cena ritual del Séder es la ingestión de ciertos alimentos simbólicos. Su simbolismo está relacionado con los sufrimientos y penalidades que pasaron los judíos en Egipto. La jaroset es una mezcla a base de manzana, miel, vino y frutos secos, en recuerdo del mortero con que los judíos levantaron las construcciones del faraón. La matzá, el pan ácimo, en recuerdo del pan que llevaron los israelitas en su huída de Egipto; la salida precipitada impidió que la levadura del pan fermentara por lo que la matzá se elabora prescindiendo de levadura. El reparto de dichos alimentos antes del comienzo de la cena ritual fue una costumbre extendida entre las comunidades sefardís.
} 
bíblicos de otros libros de la Torá ${ }^{62}$. A continuación reproducimos las palabras de Rabí Yehudá Salom ${ }^{63}$ : Hemos averiguado que la construcción del Tabernáculo guarda una estrecha relación con la Creación del mundo. El día primero fueron creados los cielos y la tierra, sobre los cuales está escrito: despliega los cielos como cortinas (Ex 26:1) y del Tabernáculo se dice: y harás cortinas (Ex 26:1). El día segundo: haya un firmamento que separe unas aguas de otras (Gn 1:6), y del Tabernáculo: y separará el velo entre el Santo y el Santísimo (Ex 26:33). El día tercero: reúnanse las aguas (Gn 1:9), y del Tabernáculo: $y$ harás una pila de bronce y pondrás en ella agua (Ex 26:33). El día cuarto: y haya luminarias (Gn 1:14), y del Tabernáculo: harás un candelabro (Ex 25:31). El día quinto: vuelen las aves (Gn 1:20), y del Tabernáculo: harás dos querubines...que extenderán sus alas (Ex 20:18-20). El día sexto: haga salir la tierra almas vivas (Gn 1:24), y del Tabernáculo: quien de vosotros ofrezca un sacrificio... lo ha de ofrecer a la entrada del Tabernáculo (Lev 1:2-3). El día séptimo todo estuvo lleno de luz, y el Tabernáculo, cuando entró Dios en su interior, resplandeció a causa de la Presencia.

No es casual, pues, la representación del Tabernáculo como cierre al ciclo bíblico. Comenzando con la Creación, y culminando con el Tabernáculo, el prólogo miniado constituye un círculo perfecto que vuelve sobre sí mismo. Esta idea de fin que rememora su principio es la misma que alimenta

\footnotetext{
${ }^{62}$ Nos hemos abstenido de incorporar el Midrash Tanhuma Yelamedenu a nuestro breve listado de obras midráshicas, por tratarse de un caso particular sobre el cual ni los propios especialistas parecen ponerse de acuerdo. Parece que en el texto que actualmente conocemos como Midrash Tanhuma Yelamedenu se confunden, en realidad, tres textos distintos. Los datos con los que se cuenta hoy en día, así como la controversia alrededor del texto aparece recogida en E. ROMERO, $L a$ Ley en la Leyenda. Relatos de tema bíblico en las fuentes hebreas, op. cit., pp. 103-106.

${ }^{63}$ Texto especifico tomado de Ibid. p. 142. Para el texto midráshico completo ver S. A. Berman, Midrash Tanhuma-Yelammedenu, New Jersey, 1996.
}

la esencia de la festividad de la Pascua, que constituye un recordatorio anual de la Liberación de Egipto, una vuelta a los principios de la existencia libre del pueblo de Israel ${ }^{64}$.

\section{A MODO DE CONCLUSIÓN}

Como se ha señalado más arriba, el cuerpo de la Torá comprende dos grandes estructuras: por un lado el cuerpo escrito, textual, recogido en los cinco libros mosaicos; por otro, el transmitido en forma oral, la Tradición. Es evidente, como emana de todo lo anteriormente expuesto, que fueron ambos universos, y no solamente la tradición textual, los que inspiraron las imágenes judías de época medieval, $y$, en nuestro caso, las del preámbulo miniado de la Hagadá de Sarajevo.

Pero estos elementos midráshicos no sólo sirvieron de inspiración a los artífices de los manuscritos judíos sino, tal y como hemos visto en algunos ejemplos, también fueron la fuente textual de miniaturas cristianas. Un análisis de los textos exegéticos rabínicos sería vital para comprender no sólo las plasmaciones veterotestamentarias en las manifestaciones artísticas del pueblo

\footnotetext{
64 Tal y como hemos indicado al comienzo, la obligación de narrar a las nuevas generaciones las maravillas hechas por Dios para redimir a los hebreos de la esclavitud de Egipto aparece ya recogida en la Torá: Y Moisés dijo al pueblo: tenéis que recordar este día en que salisteis de Egipto, de la tierra de esclavitud, porque ha sido la fuerza poderosa del Señor la que os ha sacado de aquí (...) Ex 13:3; Ese día explicarás a tus hijos: hacemos esto para recordar lo que hizo por mí el Señor cuando salí de Egipto, Ex 13:8. Pero la importancia va aún más allá, tal y como nos recuerda Maimónides en el Sefer ha Mitzvot: By this injuction we are commanded to recite the store of the Exodus from Egypt, with all the eloquence at our command, on the eve of the fifteenth of Nisan. He is to be commended who expands this theme, enlarging on the iniquity of the Egyptians and the sufferings which they inflicted on us, and on the way in which the Lord wrought his vengeance upon them, and offering Him thanks (exalted be He), precepto positivo 157 [tomado de RABÍ MOSHÉ BEN MAIMÓN, Sefer ha Mitzvot, traducción y notas a cargo de Rabbi Dr. Charles B. Chavel, dos volúmenes, Londres, 1967].
} 
hebreo, sino también en aquellas generadas en un entorno cristiano.

Pero reconocer la dependencia que las manifestaciones artísticas judías tienen de los textos hermenéuticos hebreos nos permite, además, una segunda lectura: hemos comentado la ausencia de un estilo artístico netamente judio, debido a la dependencia que las manifestaciones artísticas del pueblo hebreo tenían de la cultura artística del lugar y momento en que fueron creadas. No obstante, esta ausencia de un estilo netamente judío no significa que la miniatura hebrea no presente particularidades que le confieren entidad e identidad propias; tal vez parte de esta singularidad se cimiente en la necesidad del pueblo hebreo de crear expresiones artísticas que reflejen la unicidad de su pensamiento y de su Tradición. Parte de este pensamiento y de esta Tradición están recogidos en el Midrash y en la Hagadá.

\section{ANEXO. FUENTES COMENTADAS}

Bereshit Rabá (en hebreo, “Génesis Mayor"): Midrash hagádico del Libro del Génesis. Se nutre de fuentes orales, de leyendas, de los escritos apócrifos y de los escritos de Filón y Flavio Josefo. Es obra de los amoraitas de Palestina (en hebreo, "ínterpretes"; sucesores de los tannaitas - sabios-, su tarea fue la de profundizar y comentar los textos talmúdicos entre los siglos III y VI d. C.). Es el más antiguo entre todos los Midrash-Rabá, comentarios de los diferentes Libros Sagrados. Hemos utilizado la traducción española de Luis Vegas Montaner, Génesis Rabá I (Génesis 1-11). Comentario midráshico al libro del Génesis, Estella, 1994. Citado por capítulo y versículo correspondientes del Génesis.

Pirkei Rabí Eliezer (Capítulos de Rabí Eliezer): narración hagádica a pasajes del Génesis, Éxodo y Números. Se atribuye a Rabí Eliezer ben Hircanos, tanaíta de la segunda generación (c. 90-130 d. C), aunque los in- vestigadores se inclinan a pensar que fue redactado durante el siglo VIII, o principios del IX, en Palestina. Hemos utilizado el texto del manuscrito de Abraham Epstein, Viena, publicado en Pirkê de Rabbi Eliezer (The chapters of Rabbi Eliezer the Great), traducción y notas de Gerald Friedlander, Nueva York, 1970 [Existe una versión española del texto a cargo de Miguel Pérez Fernández, Los capítulos de Rabbí Eliezer, Valencia, 1984]. Citado por capítulo.

Shemot Rabá (en hebreo, "Éxodo Mayor"): Midrash hagádico del Libro del Éxodo. El texto que ha llegado a nosotros es el resultado de la fusión, en el siglo XI o XII, de dos textos diferentes: Shemot Rabá I (Éxodo 1-10) y Shemot Rabá II (Éxodo 12-14). Ambos son compilaciones medievales de material agádico de épocas tanaíta y amoraíta. Hemos empleado el texto hebreo editado por A. A. Leví, Midras Rabba, (en cuatro volúmenes), Jerusalén, $1959^{65}$. Los volúmenes 3 y 4 corresponden al Libro del Éxodo. Citado según capítulo y apartado de la correspondiente edición de Leví.

Talmud de Babilonia: corpus legal y de prescripciones relativas a diversas facetas de la vida de los hebreos, así como comentarios sobre la Torá. Consta de un código de leyes, denominado Mishná, y de un comentario sobre éste, la Guemará. Existen dos compilaciones del Talmud: el Talmud de Palestina (también llamado Talmud de Jerusalem), redactado entre los siglos III y V d. C, y el Talmud de Babilonia, escrito entre los siglos III y VI d. C. Fue el segundo, el Talmud de Babilonia, el aceptado por las comunidades judías en la Diáspora, y es el que se considera como más autorizado. El corpus textual se divide en seis secciones, llamadas

\footnotetext{
${ }^{65}$ Quiero agradecer de forma muy especial a Catalina Wajs, mi madre, su infinita paciencia a la hora de ayudarme a traducir los textos hebreos, así como por su insistencia para que abordase la herencia hebrea como tema central de mi futura Tesis Doctoral.
} 
sedarim (en hebreo, "órdenes"; sing. séder), dividiéndose cada una de ellas en tratados, cuyo número varía de siete a doce. La presencia hagádica en esta obra es muy variable, ya que mientras algunos de los tratados tienen un contenido puramente legal, otros abundan en textos legendarios. Hemos empleado la versión de Rabbi I. Epstein (ed.), The Babylonian Talmud, Londres, 19351948. Citado por el nombre del séder, seguido por el tratado y el folio.

Targum pseudo-Jonatán: las traducciones del texto bíblico al arameo reciben el nombre de targum (en hebreo, "traducción"; pl. targumim). Los targumim son, en la gran mayoría de los casos, traducciones parafrásticas, por lo que contienen gran cantidad de ampliaciones al texto original. El Targum pseudo-Jonatán o Targum de Jerusalén fue elaborado en Palestina, probablemente entre los siglos I y II d. C., aunque algunos retrasan su redacción final a los siglos VII u VIII d. C. En la actualidad sólo se conservan algunos fragmentos. Hemos utilizado la traducción castellana, de muy reciente aparición, de Teresa Martínez Sáiz, Traducciones arameas de la Biblia. Los Targumim del Pentateuco. I. Génesis, Estella, 2004. Citado por los correspondientes versículos. 


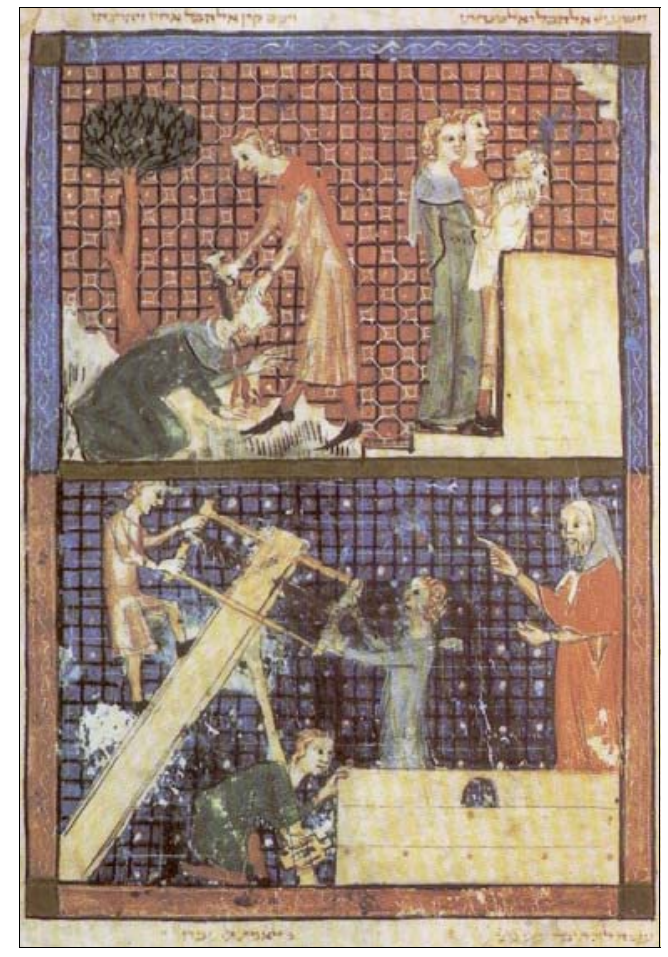

- Fig. 1. «Caín y Abel»y «Construcción del Arca de Noé», Hagadá de Sarajevo, Sarajevo, Museo Nacional de Bosnia, fol. 4r.

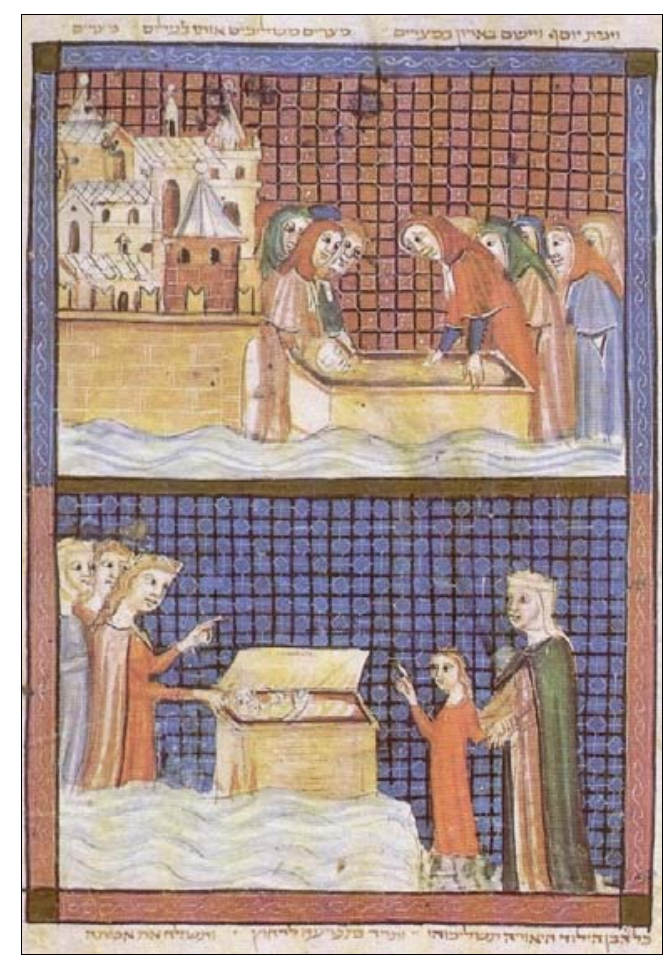

- Fig. 3. «Muerte de José» y «Rescate de Moisés », Hagadá de Sarajevo, Sarajevo, Museo Nacional de Bosnia, fol. 20r.

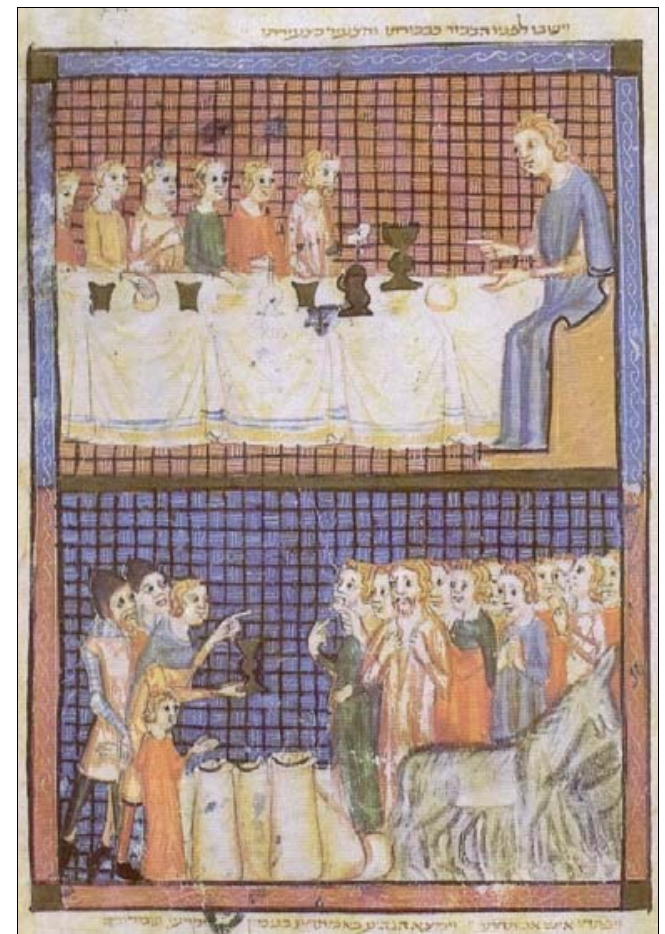

- Fig. 2. «José y sus hermanos», Hagadá de Sarajevo, Sarajevo, Museo Nacional de Bosnia, fol. 16r.

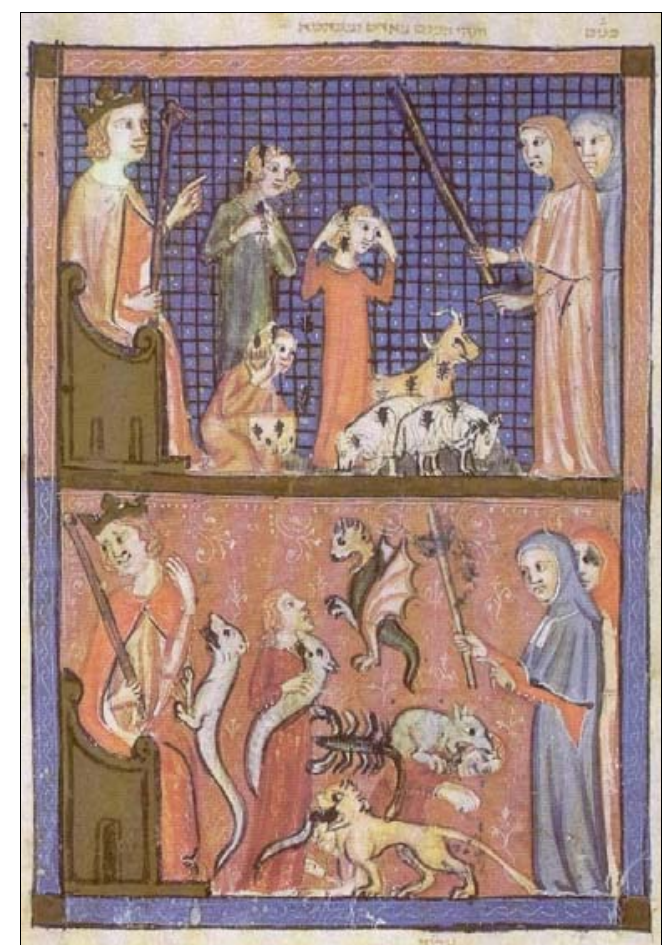

- Fig. 4. «Tercera plaga: piojos» $\mathrm{y}$ «Cuarta plaga: arov ", Hagadá de Sarajevo, Sarajevo, Museo Nacional de Bosnia, fol. 23v. 


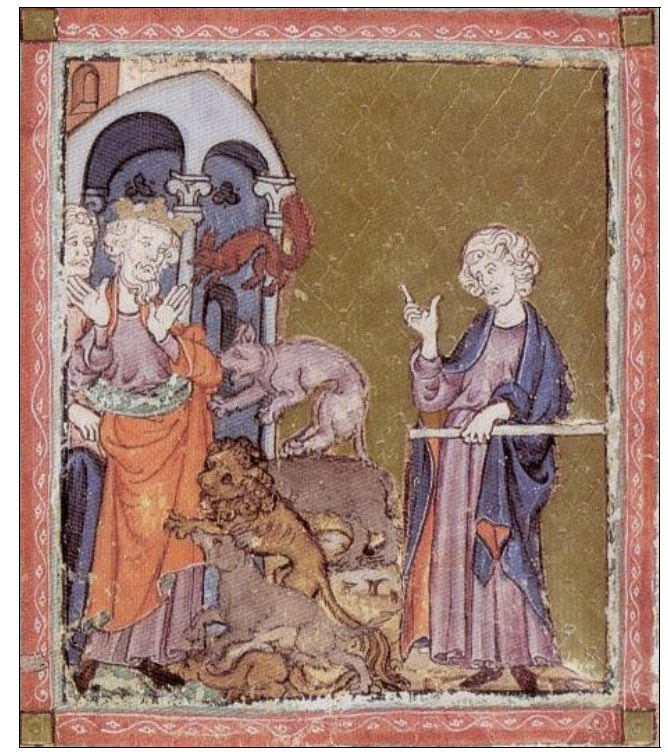

- Fig. 5. «Cuarta plaga: arov», Hagadá de Oro, Londres, The British Library (Ms. Add. 27210), fol. $12 \mathrm{v}$.

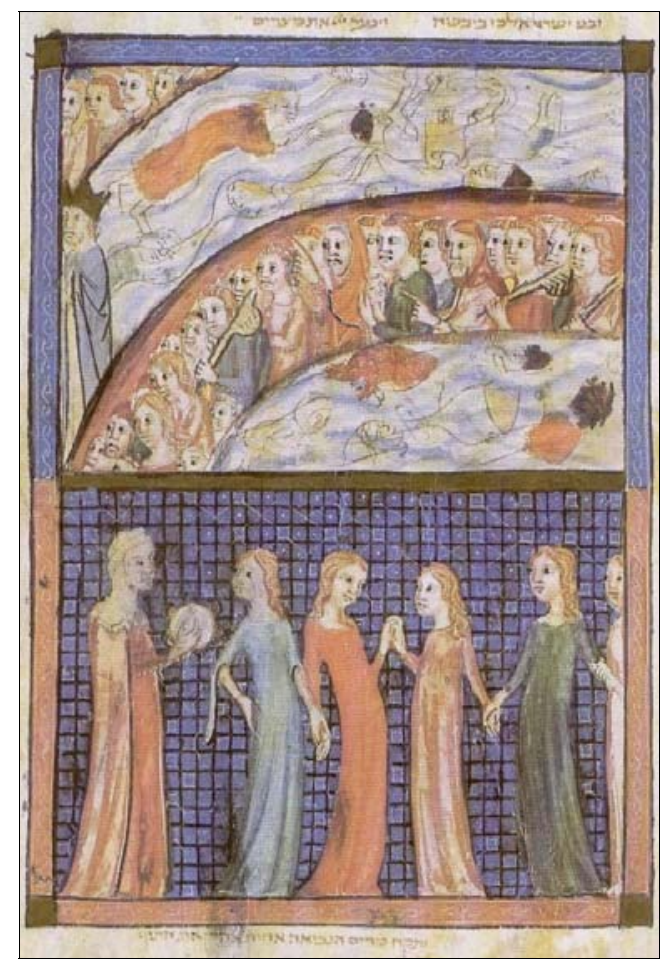

- Fig. 7. «El paso del Mar»y «Cantos y danzas de agradecimiento tras la liberación», Hagadá de Sarajevo, Sarajevo, Museo Nacional de Bosnia, fol. 28r.

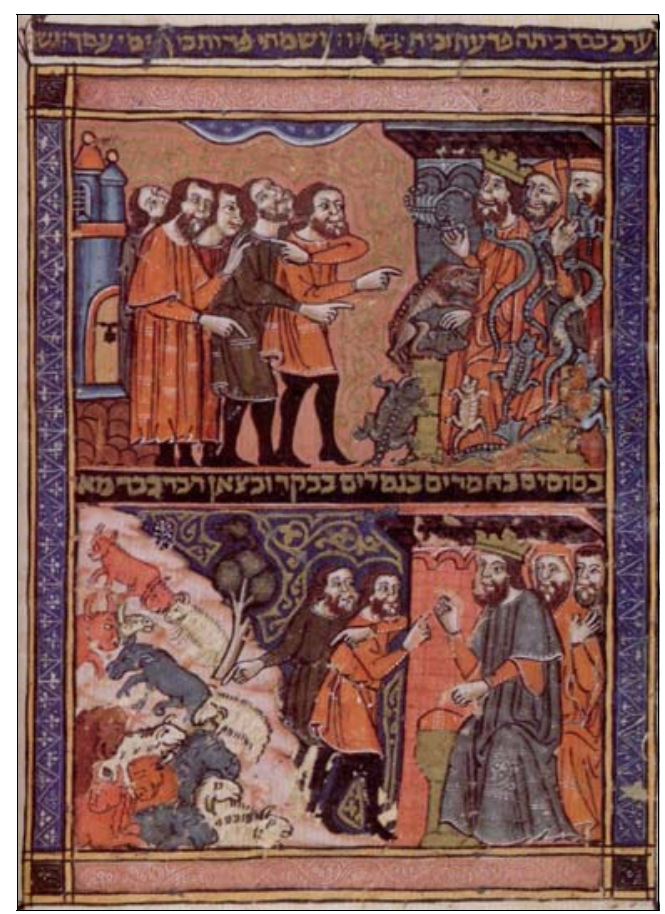

- Fig. 6. «Cuarta plaga: arov» y «Quinta plaga: peste sobre el ganado», Hagadá Rylands, Manchester, The John Rylands University Library (Ms. Ryl. Hebr. 6), fol. 16v.

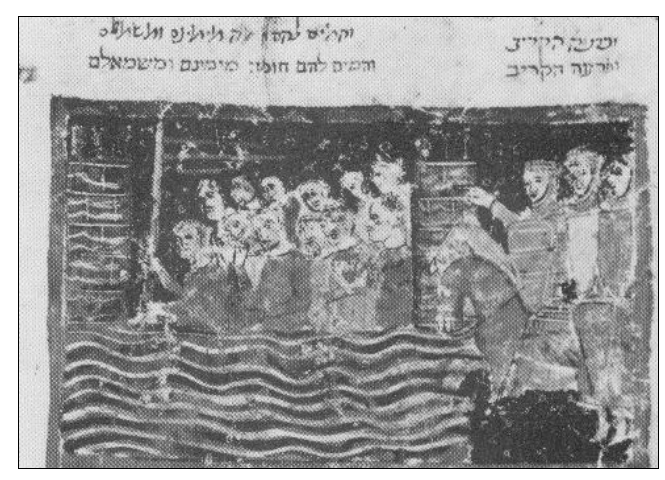

- Fig. 8. «El paso del mar», Hagadá catalana, conocida como Sister Haggada, Londres, The British Library (Ms. Add. 2884), fol. $16 \mathrm{v}$. 


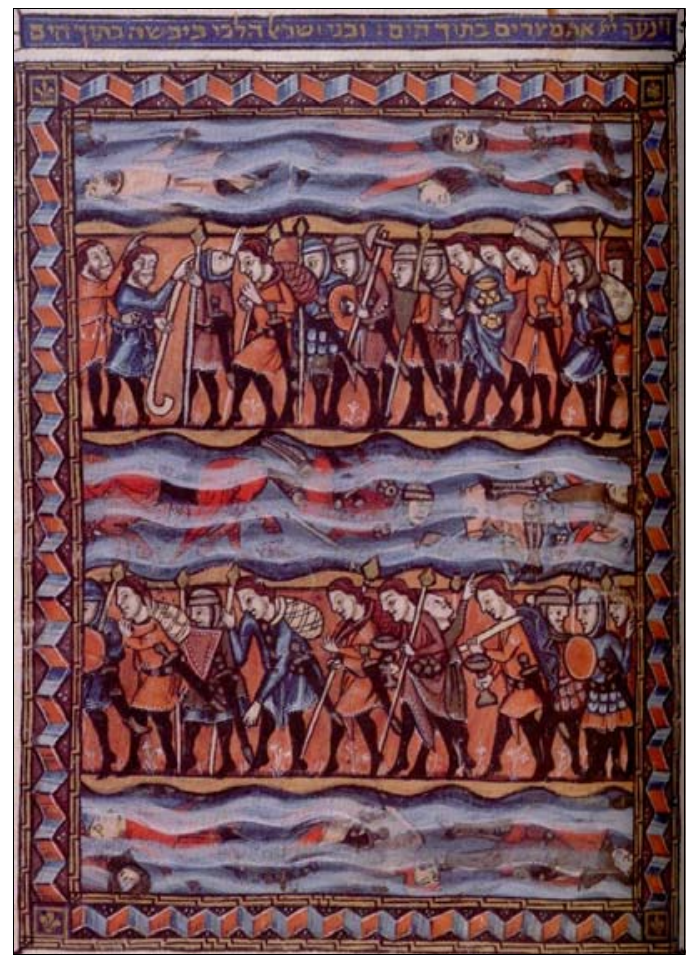

- Fig. 9. «El paso del mar», Hagadá Rylands, Manchester, The John Rylands University Library (Ms. Ryl. Hebr. 6), fol. 19r.

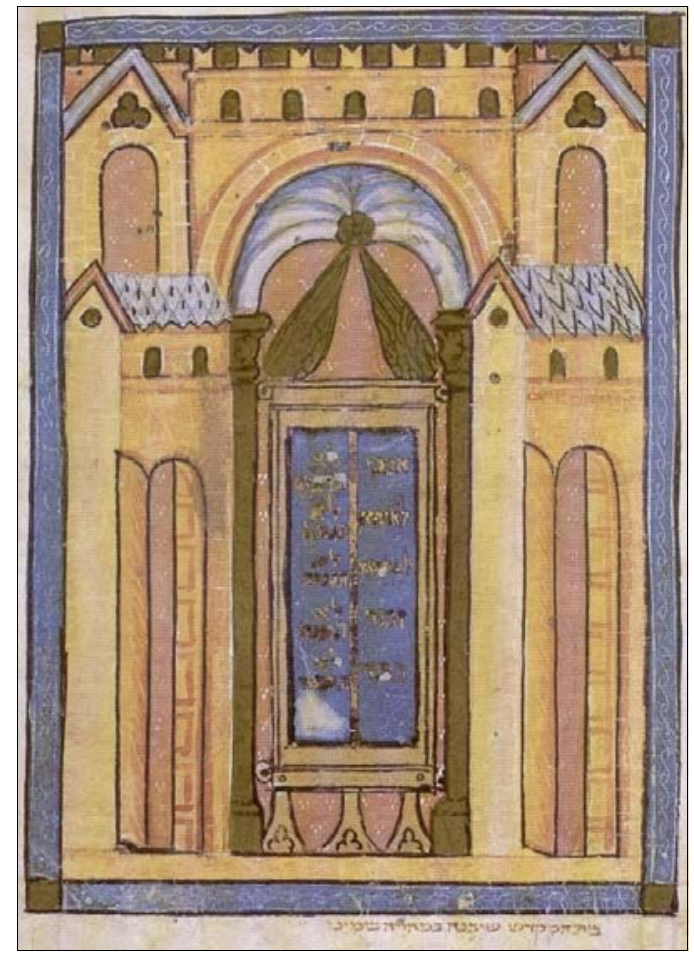

- Fig. 10. «El Templo de Jerusalem», Hagadá de Sarajevo, Sarajevo, Museo Nacional de Bosnia, fol. 32r. 